\title{
STUDI PROSES PENANGANAN LINEN DI RUMAH SAKIT EMANUEL BANJARNEGARA TAHUN 2015
}

\author{
Agnesti Endang Legowati ${ }^{1)}$, Agus Subagiyo ${ }^{2)}$ \\ Jurusan Kesehatan Lingkungan, Politeknik Kesehatan Kemenkes Semarang, \\ Jl. Raya Baturaden KM 12 Purwokerto, Indonesia
}

\begin{abstract}
Abstrak
Rumah Sakit Emanuel Banjarnegara merupakan rumah sakit Tipe C, dengan nilai (Bed Occupancy Ratio) 64,88\%, jumlah tempat tidur 180. Lingkungan rumah sakit yang kurang baik merupakan sumber potensi terjadinya infeksi nosokomial, salah satu lingkungan tersebut adalah penanganan linen. Proses penanganan linen ada beberapa tahap yang belum memenuhi standar diantaranya, pengangkutan menggunakan kereta linen yang tidak terlindungi sehingga bisa menjadi potensi cemaran bakteri. Tujuan penelitian adalah untuk mengetahui proses penanganan linen dan mendiskripsikan proses penanganan linen, jumlah rata-rata linen kotor, jenis linen serta mengetahui jumlah angka kuman spora spesies Bacillus sp. pada linen bersih setelah keluar dari proses. Jenis penelitian ini adalah deskriptif yaitu dengan cara membandingkan hasil penelitian yang dilakukan dengan teori dan peraturan yang berlaku yaitu KepMenkes RI Nomor 1204/Menkes/SK/X/2004 tentang Persyaratan Kesehatan Lingkungan Rumah Sakit. Proses penanganan linen di Rumah Sakit Emanuel Banjarnegara dalam katagori cukup baik dengan nilai $70 \%$. Hasil pemeriksaan mikrobiologi spora spesies Bacillus sp. pada seprei $\left(0,62\right.$ inc $\left.^{2}\right)$, sarung bantal (19,22 inc $\left.{ }^{2}\right)$, sarung guling (4,96\%) dan selimut (127,72 inc $\left.^{2}\right)$. Peneliti menyimpulkan proses penanganan linen masih ada yang belum baik yaitu proses pengangkutan linen kotor karena troli yang digunakan sama antara linen infeksius dan non infeksius tetapi kantongnya sudah terpisah.
\end{abstract}

Kata kunci : Penanganan, Linen Rumah Sakit, Kesehatan Lingkungan

\begin{abstract}
Emanuel Hospital is a hospital Banjarnegara Type C, with a value (Bed Occupancy Ratio) 64.88\%, the number of beds 180. The hospital environment is not good is a potential source of nosocomial infection, one of the neighborhood is the handling of linen. Linen handling process there are several stages which do not meet such standards, transport by train linen unprotected so that could be a potential bacterial contamination. The research objective was to determine and describe the process of handling linen linen handling process, the average amount of dirty linen, linen type and number of bacteria spores know the number of species of Bacillus sp. on clean linen after the exit of the process. This type of research is descriptive, by comparing the results of research conducted with the theory and regulations that Kepmenkes No. 1204 / Menkes / SK / X / 2004 on Environmental Health Requirements Hospital. Linen handling process at Emanuel Hospital Banjarnegara quite well in the category with a score of 70\%. Results of microbiological examination of spores of species Bacillus sp. on the bed linens (0.62 inc2), pillowcases (19.22 inc2), tube case (4.96\%) and blankets (127.72 inc2). Researchers concluded linen handling process there are not good, that the process of transporting the dirty linen trolley used for collaboration between infectious and noninfectious linen but has a separate pocket.
\end{abstract}

Keywords $\quad$ : Handling, Hospital Linen, Environmental Health

\section{PENDAhuluan}

Linen rumah sakit adalah bahan atau kain yang digunakan di rumah sakit untuk kebutuhan pembungkus kasur, bantal, guling dan alat instrument steril lainnya. Linen kotor rumah sakit merupakan sumber infeksi yang dapat menjadi perantara tertularnya penyakit dari orang yang menderita penyakit infeksius ke orang lain yang mempunyai daya tahan tubuh rendah. Linen kotor terbagi menjadi dua macam, yaitu : linen infeksius dan linen non infeksius. Linen infeksius adalah linen yang terkontaminasi oleh darah, cairan tubuh, sekresi dan eksresi manusia

(http://www.slideshare.net/yusufbadurohman/pengelo laan-linen-kotor).

Penanganan linen merupakan tanggung jawab bagian laundry yang memiliki tata laksana berupa ketersediaan kran air bersih dan air panas, tersedia mesin cuci yang terpisah untuk linen infeksius dan non infeksius, memiliki ruangan yang terpisah sesuai 
kegunaan seperti ruang linen kotor, ruang linen bersih dan ruang kereta linen. Standar kuman bagi linen bersih setelah keluar dari proses tidak boleh terdapat spora spesies Bacillus lebih dari $6 \times 10^{3}$ per inci persegi (Kepmenkes 1204/ Menkes/ SK/ X/ 2004, h. 33).

Salah satu rumah sakit yang berada di Kabupaten Banjarnegara adalah Rumah Sakit Emanuel yang berlokasi di Jl. Ahmad Yani, Purworejo Klampok, Banjarnegara - Jawa Tengah 53474, Telp 0286479030 dan Fax 0286-479032. Rumah sakit ini diresmikan pada 31 Mei tahun 1970 dibawah naungan Yayasan Kristen Untuk Kesehatan Umum (YAKKUM) dan rumah sakit ini merupakan rumah sakit dengan type C. Luas tanah 17.475M2, luas bangunan 13.268M2 dan luas lantai dasar 9.301M2.

Rumah sakit Emanuel Banjarnegara mempunyai tempat tidur sejumlah 180 buah dengan 174 untuk rawat inap dengan berbagai jenis kelas dan 6 buah untuk di ruang ICU. Berdasarkan survei pendahuluan yang dilakukan oleh peneliti yaitu mendapatkan jumlah BOR sebesar 64,88 \%. Pada bagian penanganan linen, untuk jumlah rata-rata linen kotor yang masuk perhari kurang lebih sejumlah 18,02 kg yang sumbernya dari berbagai bagian di rumah sakit ini.

Tujuan penelitian ini adalah mengetahui proses penanganan linen di Rumah Sakit Emanuel Banjarnegara Tahun 2015.

\section{BAHAN DAN CARA}

Jenis penelitian ini adalah deskriptif. Penelitian hanya menggambarkan tentang proses penanganan linen di Rumah Sakit Emanuel Banjarnegara. Subyek penelitian adalah proses penanganan linen di Rumah Sakit Emanuel Banjarnegara Tahun 2015 yaitu mengenai jumlah rata-rata linen perbulan, jenis linen yang dilaundry, dan kualitas linen dengan menghitung jumlah angka kuman spora spesies Bacilus pada linen bersih setelah dicuci di instalasi penanganan linen. Cara pemeriksaan angka kuman pada linen yaitu dengan metode usap.

\section{III.HASIL DAN PEMBAHASAN HASIL}

\section{Hasil}

Rumah Sakit Emanuel adalah sebuah Rumah Sakit milik YAKKUM, dengan 180 TT (tempat tidur) yang terbagi menjadi beberapa kelas. Rumah Sakit Emanuel berdiri diatas tanah seluas $17.475 \mathrm{~m}^{2}$ luas bangunan $13.268 \mathrm{~m}^{2}$, luas lantai dasar $9.301 \mathrm{~m}^{2}$. Secara Geografis RS Emanuel terletak di jalur jalan penghubung kota Banjarnegara-Banyumas, yaitu 30 km kea rah barat dari kota Banjarnegara, 15 km kearah selatan dari kota Purbalingga. RS.Emanuel terletak disebuah desa Purwareja Kecamatan Purwareja Klampok Banjarnegara.

Dari penelitian diperoleh hasil bahwa rata-rata jumlah linen kotor perbulan di Rumah Sakit Emanuel Banjarnegara adalah bulan Maret (165 kg) , April
(159 kg), dan Mei (170,5 kg). Jenis linen yang laundry adalah sprei, sarung bantal, sarung guling, stik laken, baju operasi petugas, baju operasi pasien, jas operasi, selimut, perlak, duk lubang, baju bayi, perlak, korden.

Hasil checklist menunjukan tahap pengumpulan termasuk katagori baik (100\%), tahap pengangkutan termasuk katagori kurang baik (50\%), tahap penerimaan termasuk katagori baik (100\%), tahap pencucian termasuk katagori cukup baik (70\%), tahap pengeringan termasuk katagori cukup baik (66,67\%), tahap penyetrikaan termasuk katagori kurang baik (50\%), tahap penyimpanan termasuk katagori cukup baik (75\%), tahap pendistribusian termasuk katagori kurang baik (50\%) dan tahap sterilisasi katagori baik (100\%), tahap penggantian linen katagori baik (100\%) dan tahap pemasangan linen bersih katagori baik (100\%).

Hasil pemeriksaan mikrobiologi spora spesies Bacillus sp. pada seprei $\left(0,62\right.$ inc $\left.^{2}\right)$, sarung bantal $\left(19,22\right.$ inc $\left.^{2}\right)$, sarung guling (4,96\%) dan selimut $\left(127,72\right.$ inc $\left.^{2}\right)$ masih dibawah standar yang ditetapkan Kepmenkes Republik Indonesia nomor 1204/MENKES/SK/X/2004 sebesar $6 \times 10^{3}$ per inc persegi.

\section{Pembahasan}

Rumah Sakit Emanuel adalah sebuah Rumah Sakit milik YAKKUM, dengan 180 TT (tempat tidur) yang terbagi menjadi beberapa kelas. Rumah Sakit Emanuel berdiri diatas tanah seluas $17.475 \mathrm{~m} 2$, luas bangunan $13.268 \mathrm{~m} 2$, luas lantai dasar $9.301 \mathrm{~m} 2$. Secara Geografis RS. Emanuel terletak di jalur jalan penghubung kota Banjarnegara-Banyumas, yaitu 30 km kea rah barat dari kota Banjarnegara, 15 km kearah selatan dari kota Purbalingga. RS.Emanuel terletak disebuah desa Purwareja Kecamatan Purwareja Klampok Banjarnegara.

Pelayanan RS Emanuel meliputi Pelayanan Spesialis, IGD, Poliklinik umum, Rawat jalan dan Rawat Inap serta pelayanan penunjang Laboratorium, Radiologi, Farmasi 24 jam, Instalasi Gizi, Instalasi PSSL , Unit kendaraan ambulan. Salah satu program utama penerapan Keselamatan Pasien Rumah Sakit (KPRS) adalah pelaporan insiden. Pelaporan ini akan menggerakan berbagai proses lanjutan seperti analisis terhadap insiden akibat-akibatnya.

Rumah Sakit Emanuel Banjarnegara mempunyai nilai BOR (Bed Occupancy Ratio) 64,88 \% pada tahun 2014. Kapasitas tempat tidur yang dimiliki Rumah Sakit Emanuel Banjarnegara sebanyak 180 tempat tidur (TT) yang terbagi menjadi kelas VVIP 6 TT, kelas VIP 4 TT, kelas utama 26 TT, kelas I 42 TT, kelas II 41 TT dan untuk kelas III sejumlah 55 TT.

Proses penanganan linen yang di persyaratkan pada Keputusan Mentri Kesehatan Republik Indonesia nomor 1204/MENKES/SK/X/2004 untuk perlakuan terhadap linen berupa tahap pengumpulan, tahap pengangkutan, tahap penerimaan, tahap 
pencucian, tahap pengeringan, tahap penyetrikaan, tahap sterilisasi, tahaap penyimpanan linen bersih, tahap pendistribusian linen bersih, penggantian lien dan pemasangan linen bersih.

Pengamatan yang dilakukan menggunakan cheklist, pada proses penanganan linen di Rumah Sakit Emanuel Banjarnegara mendapatkan nilai 70\% termasuk dalam katagori cukup baik, dengan item penilaian sebagai berikut :

a. Pengumpulan

Linen kotor pada setiap ruangan dikumpulkan menggunakan kantong yang berwarna biru tua. Khusus untuk linen infeksius dilapisi kantong plastik warna kuning yang kemudian dimasukan kedalam kantong linen kotor yaitu berwarna biru tua.

Menurut Kepmenkes 1204 tahun 2004 pada proses pengumpulan harusnya dilakukan pemilahan antara linen infeksius dan non infeksius, kemudian menghitung dan mencatat linen kotor diruangan.

b. Pengangkutan

Linen kotor diantar kelaundry dengan menggunakan troli linen yang berkantong menggunakan kantong warna biru tua, untuk linen yang infeksius dilapisi kantong plastic warna kuning yang kemudian dimasukkan kedalam kantong berwarna biru tua.

Petugas pengangkut linen sudah memakai Alat Pelindung Diri (APD) yang berupa masker dan sarung tangan ketika melakukan proses pengangkutan.

c. Penerimaan

Dilakukan pemilahan berdasar tingkat kekotoran linen, dan linen kotor yang akan dicuci di timbang beratnya. Penimbangan dilakukan untuk menyesuaikan penggunaan desinfektan dan menyesuaikan dengan kapasitas mesin cuci.

Di dalam penerimaan linen, linen ditimbang terlebih dahulu kemudian dicatat didalam buku data jumlah linen perhari perkg yang dicuci di Rumah Sakit Emanuel Banjarnegara. Linen kemudian dinaikkan keatas keruang pengelolaan linen, diatas linen diterima dan dipilah-pilah menurut tingkat kekotorannya dan dicatat menurut jenis dan ruangannya.

d. Pencucian

Proses pencucian linen dibedakan antara linen infeksius dan non infeksius, karena untuk linen infeksius ada proses perendaman terlebih dahulu menggunakan desinfektan chlorin 5\% yang direndam selama 2 jam hingga 1 hari.

Pemberian diterjen tidak menggunakan takaran yang sesuai karena petugas hanya memperkirakannya sesuai kebutuhan. Petugas harus menggunakan alat pelindung diri yang lengkap seperti baju kerja khusus, sarung tangan, apron plastik, masker, sepatu bot dan penutup kepala agar petugas dapat terlindung dari gangguan kesehatan yang disebabkan oleh linen infeksius.

e. Pengeringan

Pengeringan yang dilakukan di instalasi pengelolaan linen dilakukan dengan dua cara yaitu dengan mesin cuci dan dengan sinar matahari. Pengeringan dilakukan dengan proses pemerasan terlebih dahulu dengan mesin yang berkapasitas $20 \mathrm{~kg}$ yang selanjutnya dijemur dibawah sinar matahari.

Proses pengeringan menggunakan sinar matahari dilakukan di tempat penjemuran dan petugas seharusnya menggunakan alat pelindung diri yang lengkap seperti baju kerja khusus, sarung tangan, masker, spatu bot dan penutup kepala agar tidak terjadi kontaminasi silang pada linen yang telah di cuci.

f. Penyetrikaan

Penyetrikaan menggunakan mesin setrika rol dengan suhu $120^{\circ} \mathrm{C}$ dan pekerja hanya menggunakan masker tanpa menggunakan alat pelindung diri yang lain seperti baju kerja khusus, sarung tangan dan penutup kepala.

g. Penyimpanan

Linen yang sudah disetrika kemudian dimasukan kedalam lemari penyimpanan linen bersih yang ditata secara rapi, bebas debu dan tidak lembab. Untuk sistem penyimpanannya menggunakan sistem FIFO (First In First Out) yaitu linen yang masuk duluan maka keluar duluan.

h. Pendistribusian

Pendistribusian menggunakan troli yang sama dengan pengangkutan linen kotor, hanya saja setelah digunakan untuk mengangkut linen kotor troli dibersihkan dengan disemprot menggunakan alkohol, barulah digunakan untuk mengangkut linen yang telah bersih yang kemudian didistribusikan kemasing-masing bagian.

Kantong pembawa linen bersih berbeda dengan kantong pembawa linen kotor, untuk kantong pembawa linen bersih berwarna biru muda yang ditutup rapat.

i. Sterilisasi

Linen yang digunakan untuk instalasi bedah sentral dilakukan sterilisai menggunakan autoclave tuttnauer 5596. Alat sterilisasi tidak terdapat pada instalasi pengelolaan linen tetapi ditempatkan pada ruang control sterile supply department. Linen bersih dibawa menggunakan troli khusus yang berpenutup dari instalasi pengelolaan linen menuji control sterile supply department oleh petugas dan dilakukan sterilisasi dengan prosedur yang benar.

j. Penggantian linen

Linen yang digunakan oleh pasien di ruang rawat inap diganti sehari sekali dan bila terkena noda darah, muntahan, dahak maka linen akan langsung diganti oleh petugas agar bakteri yang 
ada dilinen tidak menumpuk dan mengganggu kesehatan pasien.

k. Pemasangan linen bersih

Linen bersih digunakan sesuai dengan peruntukannya agar memberikan rasa nyaman terhadap pasien dan linen bersih memiliki cadangan agar bila sewaktu - waktu linen bersih yang digunakan kotor dapat langsung di ganti.

Hasil pemeriksaan mikrobiologi spora spesies Bacillus sp. pada seprei $\left(0,62\right.$ inc $\left.^{2}\right)$, sarung bantal $\left(19,22\right.$ inc $\left.^{2}\right)$, sarung guling (4,96\%) dan selimut $\left(127,72\right.$ inc $\left.^{2}\right)$ masih dibawah standar yang ditetapkan Kepmenkes Republik Indonesia nomor 1204/MENKES/SK/X/2004 sebesar 6 x $10^{3}$ per inc persegi disebabkan oleh proses penyetrikaan yang menggunakan mesin setrika dengan suhu $120^{\circ} \mathrm{C}$.

\section{IV.KESIMPULAN}

Dari hasil penelitian dapat disimpulkan bahwa rata-rata jumlah linen kotor perbulan di Rumah Sakit Emanuel Banjarnegara adalah bulan Maret (165 kg), April (159 kg), dan Mei (170,5 kg). Jenis linen yang laundry adalah sprei, sarung bantal, sarung guling, stik laken, baju operasi petugas, baju operasi pasien, jas operasi, selimut, perlak, duk lubang, baju bayi, perlak, korden.

Hasil checklist menunjukan tahap pengumpulan termasuk katagori baik (100\%), tahap pengangkutan termasuk katagori kurang baik (50\%), tahap penerimaan termasuk katagori baik (100\%), tahap pencucian termasuk katagori cukup baik (70\%), tahap pengeringan termasuk katagori cukup baik (66,67\%), tahap penyetrikaan termasuk katagori kurang baik (50\%), tahap penyimpanan termasuk katagori cukup baik (75\%), tahap pendistribusian termasuk katagori kurang baik (50\%) dan tahap sterilisasi katagori baik (100\%), tahap penggantian linen katagori baik (100\%) dan tahap pemasangan linen bersih katagori baik (100\%).

Hasil pemeriksaan mikrobiologi spora spesies Bacillus sp. pada seprei $\left(0,62\right.$ inc $\left.^{2}\right)$, sarung bantal $\left(19,22\right.$ inc $\left.^{2}\right)$, sarung guling (4,96\%) dan selimut $\left(127,72\right.$ inc $\left.^{2}\right)$ masih dibawah standar yang ditetapkan Kepmenkes Republik Indonesia nomor 1204/MENKES/SK/X/2004 sebesar 6 x $10^{3}$ per inc persegi.

\section{DAFTAR PUSTAKA}

Adisasmito W., 2008. Audit Lingkungan Rumah Sakit. Rajawali Pers, Jakarta.

Alfian Mubarak, 2014, Studi Sanitasi Pengelolaan Linen Di Rumah Sakit Umum Daerah Hj. Anna Lasmanah Banjarnegara, Banjarnegara; Kementrian Kesehatan RI Politeknik Kesehatan Kemenkes Semarang Jurusan Kesehatan Lingkungan.
Departemen Kesehatan republik Indonesia, 2009. Undang-Undang Kes. RI No. 36 Tahun 2009 Tentang Kesehatan, Jakarta; Departemen Kesehatan.

Djasio Sanoprie, dkk, 1989. Komponen Sanitasi Rumah Sakit Untuk Institusi Pendidikan Tenaga Sanitasi, Jakarta: Pusat Pendidikan Tenaga Kesehatan.

http://eprints.undip.ac.id/6476/1/Manajemen Linen Rumah Sakit - Bambang Shofari.pdf-Manajemen Linen Rumah Sakit, tanggal akses 09 Februari 2014 pukul 08.00 WIB.

http://savitrirachmawati.wordpress.com/2012/12/13/b acillus-sp/

http://tahubronta.wordpress.com/2011/02/05/rumahsakit-umum-banjarnegara-jl-sudirman-no-42banjarnegara-telp-0268\%C2\%A091464\%C2\%A0\%C2\%A0-fax-\%C2\%A00268-59-2462/, tanggal akses 09 Februari 2014 pukul 08.00 WIB.

http://www.slideshare.net/yusufbadurohman/pedoma n-manajemen-linen-rs, tanggal akses 09 Februari 2014 pukul 08.00 WIB.

http://www.slideshare.net/yusufbadurohman/pengelol aan-linen-kotor, tanggal akses 09 Februari 2014 pukul 09.00 WIB.

Indonesia, Dirjen PPM dan PLP, 1994 Pedoman Sanitasi Rumah Sakit di Rumah Sakit, Departemen Kesehatan RI. Jakarta

Kepmenkes RI nomor 1204/MENKES/SK/X/2004 Tentang Persyaratan Kesehatan Lingkungan Rumah Sakit.

Sapta Raharas, 1997. Manajemen Linen dan Laundry di Rumah Sakit, Pokja Kajian Pelayanan Kesehatan, Pusat Penelitian Kesehatan Universitas Indonesia Jakarta

Suharsini Arikunto, 1998, Pedoman Penelitian Suatu Pendekatan Praktis, Jakarta; Rineka Cipta

Tri Cahyono, 2014, Pedoman Penulisan Proposal Penelitian dan Karyatulis Ilmiah / Skripsi, Kementrian Kesehatan Republik Indonesia Politeknik Kesehatan Kementrian Kesehatan Semarang Jurusan Kesehatan Lingkungan Purwokerto 